Winter 2009

\title{
Integration of Corporate Social Responsibility Through International Voluntary Initiatives
}

Tim Baines

London School of Economics and Political Science

Follow this and additional works at: https://www.repository.law.indiana.edu/ijgls

Part of the Business Organizations Law Commons, and the International Law Commons

\section{Recommended Citation}

Baines, Tim (2009) "Integration of Corporate Social Responsibility Through International Voluntary Initiatives," Indiana Journal of Global Legal Studies: Vol. 16 : Iss. 1 , Article 8.

Available at: https://www.repository.law.indiana.edu/ijgls/vol16/iss1/8

This Symposium is brought to you for free and open access by the Law School Journals at Digital Repository @ Maurer Law. It has been accepted for inclusion in Indiana Journal of Global Legal Studies by an authorized editor of Digital Repository @ Maurer Law. For more information, please contact rvaughan@indiana.edu.

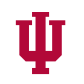

JEROME HALL LAW LIBRARY

INDIANA UNIVERSITY

Maurer School of Law
Blooming ton 


\title{
Integration of Corporate Social Responsibility Through International Voluntary Initiatives
}

\author{
Tim Baines*
}

\begin{abstract}
Many multinational companies and financial institutions have adopted corporate social responsibility programs, often relying on the implementation of international voluntary initiatives. This article describes two such mechanisms. The first, the Equator Principles, provides guidance to financial institutions involved in project finance. The second, the Organization for Economic Cooperation and Development's Guidelines for Multinational Enterprises, helps governments to encourage businesses to be socially and environmentally responsible. This article suggests means by which voluntary initiatives can be implemented to benefit both the wider community and companies themselves. It also suggests ways of overcoming shortcomings resulting from the lack of access to formal legal sanctions when implementing voluntary initiatives.
\end{abstract}

\section{INTRODUCTION}

Many multinational enterprises (MNEs) and international financial institutions have formally adopted corporate social responsibility ${ }^{1}$ (CSR) programs. The time and effort consumed by CSR is illustrated by a number of factors, including the long list of international events that form the annual CSR calendar, indices such as the Dow Jones Sustainability Indexes, FTSE4Good, and the array of vol-

* L.L.B., London School of Economics and Political Science. Associate, Dewey \& LeBeouf LLP, London, U.K.

1. This article deliberately sidesteps the debate over what CSR is and how it should be defined. However, for those entirely unfamiliar with the concept, a useful working definition has been provided by the European Commission. The Commission defines CSR as "[a] concept whereby companies decide voluntarily to contribute to a better society and a cleaner environment." Commission Green Paper on Employment and Social Affairs, Promoting a European Framework for Corporate Responsibility, at 5, COM (2001) 366 final (July 2001).

Indiana Journal of Global Legal Studies Vol. 16 \#1 (Winter 2009)

OIndiana University Maurer School of Law - Bloomington 
untary initiatives that have been adopted by MNEs keen to embed CSR and to demonstrate their corporate credentials.

Despite this trend, MNEs continue to act in ways that do not accord with the spirit of good CSR. ${ }^{2}$ This is not surprising for a number of reasons. First, there is legal and academic uncertainty about whether or not corporations have any social "responsibility" at all. ${ }^{3}$ Second, even assuming that corporations should act in a socially responsible manner, it has been impossible to identify a definitive concept of CSR. Third, MNEs continue to be protected by a lack of legal regulation or enforcement in some jurisdictions. Finally, and perhaps most importantly, MNEs, particularly Anglo-American MNEs, have wholeheartedly accepted the economic theory underpinned by the notion that "the business of business is business."

As a result, while there has been increasing scrutiny of MNEs' global social and environmental impacts, particularly in the area of human rights, and implementation of international, all-encompassing CSR reporting, the implementation of established CSR programs by MNEs remains a relatively new phenomenon. Perhaps the reason for this is that MNEs have been slow to understand their ability to use CSR in a manner that enhances corporate opportunities and competitiveness. They have not recognized that CSR has the potential to improve a company's social and environmental impacts and limit reputational damage, while at the same time improving its profitability.

This article does not seek to define the concept of CSR or to determine whether or not the pursuit of CSR by MNEs is, in reality, beneficial (either for MNEs themselves or for their stakeholders). CSR is now so much a part of the corporate landscape that it has become as important to look at how MNEs implement CSR strategy as it is to question their motives. This article therefore focuses on one of the predominant aspects of CSR implementation by MNEs-the voluntary adoption of international CSR initiatives. Such initiatives are not necessarily categorized as CSR

2. Examples of such behavior are tracked by an array of non-governmental organizations. See, e.g., Banktrack, Private Finance: A Public Interest, http://www.banktrack.org (last visited Oct. 6, 2008); Ethical Corporation Institute, http://www.ethicalcorporationinstitute.com/ (last visited Oct. 6, 2008).

3. "What does it mean to say that "business' has responsibilities? Only people can have responsibilities. A corporation is an artificial person, and in this sense, may have artificial responsibilities, but 'business' as a whole cannot be said to have responsibilities, even in this vague sense." Milton Friedman, The Social Responsibility of Business is to Increase its Profits, N.Y. TIMEs, Sept. 13, 1970, at 33 .

4. This theory, associated with Milton Friedman, states that companies should focus on returning shareholder value. 
performance or implementation initiatives and indicators (though some of them are), ${ }^{5}$ but all play a prominent role in many MNEs' CSR strategies.

This article will focus on the Equator Principles (EPs) ${ }^{6}$ and the Organization for Economic Cooperation and Development (OECD) Guidelines for Multinational Enterprises (the Guidelines). ${ }^{7}$ After reviewing each initiative's purposes, tenets, and influence on MNEs, this article will use the criteria outlined by Harvard Business School Professors Michael Porter and Mark Kramer ${ }^{8}$ to test the extent to which these initiatives enable organizations to embed CSR into their daily operations and to fully capitalize on the benefits that CSR offers. This article will then address the criticism that the voluntary nature and the lack of formal legal sanction of voluntary CSR initiatives is an Achilles heel that renders these initiatives inherently unfit for their purpose. Finally, this article will suggest how such initiatives could be altered in order to improve the implementation of CSR by MNEs and financial institutions.

\section{Two Key Initiatives}

\section{A. The Equator Principles}

\section{What They Are}

The EPs provide an extremely important example of a voluntary CSR initiative adopted by many leading financial institutions. ${ }^{9}$ The adoption of the EPs represents one of the first instances in which competing financial institutions have come together to agree upon a detailed framework for the implementation of improvements in their social and environmental practices.

The EPs are voluntary social and environmental guidelines to which over

5. One example of this is voluntary CSR reporting in accordance with the Global Reporting Initiative's recommendations. See Global Reporting Initiative, G3 Online, http://www.globalr eporting.org/ReportingFramework/G3Online/ (last visited Nov. 13, 2008).

6. The Equator Principles (July 2006), http://www.equator-principles.com/documents/ Equator_Principles.pdf [hereinafter Equator Principles or EPs].

7. Organization for Economic Cooperation and Development [OECD], The OECD Guidelines for Multinational Enterprises (2000), available at http://www.oecd.org/dataoecd/56/36/1922428.pdf [hereinafter OECD Guidelines].

8. Michael E. Porter \& Mark R. Kramer, Strategy \& Society: The Link Between Competitive Advantage and Corporate Social Responsibly, HARv. Bus. Rev., Dec. 2006, at 78.

9. A more detailed description of how the EPs work is set out in Paul Q. Watchman et al., EP 2: The Revised Equator Principles: Why Hard-nosed Bankers are Embracing Soft Law Principles, LAW \& FIN. MKTS. Rev., Mar. 2007, at 85. 
sixty banks and financial institutions (together, the Equator Principles Financial Institutions, or EPFIs) have agreed to be bound. They do not contain a detailed set of enforceable legal norms, but rather a general framework of ten broad principles underpinned by International Finance Corporation (IFC) Performance Standards ${ }^{10}$ and the application of local and national law. ${ }^{11}$

The EPs comprise two sets of principles. The first set, EPl, was conceived with the help of the IFC in 2002 and was launched in 2003. The second revised set, EP2, has been open for adoption by EPFIs since July $2006 .{ }^{12}$ Under the EPs, EPFIs agree not to provide loans to a project unless sponsors can demonstrate that the project will be constructed and operated in accordance with sound social and environmental management practices.

\section{How They Work}

The EPs require projects to be categorized as A, B, or C projects in accordance with the degree of risk the project presents to society or the environment. ${ }^{13}$ The following table describes the categories by risk:

\section{Table i: Project Characterization ${ }^{14}$}

Category A: High Risk Projects with potential significant adverse social or environmental impacts that are diverse, irreversible, or unprecedented.

Category B: Medium Risk Projects with potentially limited adverse social and environmental impacts that are few in number, generally site specific, largely reversible, and readily addressed through mitigation measures.

Category C: Low/No Risk Projects with minimal or no social or environmental impacts.

Category $\mathrm{A}$ and Category $\mathrm{C}$ projects are relatively easy for EPFIs to identify as they will be the highest- and lowest-risk projects, respectively. If a project is categorized as a Category B project, the applicable requirements differ depending

10. International Finance Corporation, Performance Standards on Social and Environmental Sustainability (Apr. 30, 2006), http://www.ifc.org/ifcext/sustainability.nsf/AttachmentsByTitle/ pol_PerformanceStandards2006_full/\$FILE/IFC+Performance+Standards.pdf.

11. Equator Principles, supra note 6, princ. 3.

12. Equator Principles, supra note 6.

13. Id. exhibit II.

14. See Freshfields Bruckhaus Deringer, Banking on Responsibility 30-32 (2005). 
upon whether the project is located in a non-OECD country or a non-High-Income OECD country, as defined by the World Bank Development Indicators. ${ }^{15}$ Regardless of this distinction, it may be considered appropriate to subject certain projects to a certain requirement. Those requirements are described as follows:

\section{TABle 2: EPFI REQUiREMENTS FOR CATEgory A ANd Category B Projects ${ }^{16}$}

\begin{tabular}{|l|l|l|}
\hline Requirement & Category A & Category B \\
\hline $\begin{array}{l}\text { Carry out Environmental and Social Impact } \\
\text { Assessment }\end{array}$ & All Category A & All Category B \\
\hline $\begin{array}{l}\text { Implement Social and Environmental Action } \\
\text { Plan and Management System }\end{array}$ & All Category A & Category B* \\
\hline Carry out Public Consultation & All Category A & Category B*\# \\
\hline Instigate Grievance Procedures & All Category A & Category B*\# \\
\hline Subject project to Independent Expert Review & All Category A & Category B\# \\
\hline Subject project to Independent Monitoring & All Category A & Category B\# \\
\hline Annual Reporting Obligations & All Category A & All Category B \\
\hline $\begin{array}{l}\text { Loan Covenants: } \\
\text { Materially comply with applicable social and } \\
\text { environmental laws, regulations, and } \\
\text { permits }\end{array}$ & All Category A & Category B* \\
$\begin{array}{l}\text { Materially comply with the Action Plan } \\
\text { Compliance and Enforcement mechanism: } \\
\text { Compliance with Decommissioning Plan }\end{array}$ & & \\
\hline
\end{tabular}

\section{KEY}

*Non-OCED counries and Non-High-Income OCED countries \#When appropriate to subject the project to requirement

Since the adoption of EP1, EPFIs have been required to review loan documentation in light of the wider environmental (and in the case of EP2, social) assessment, monitoring, and enforcement obligations to which they have agreed to be bound. EP2 has introduced borrower covenants that must be incorporated into loan documentation. ${ }^{17}$ These covenants are set out in the table above.

15. Equator Principles, supra note 6, princs. 3-6; WORLD BANK, WORLD DEVELOPMENT INDICATORS 2008 (2008).

16. See Equator Principles, supra note 6, princs. 3-6.

17. Id. princ. 8. 
The EPs provide no ombudsman or alternative means of redress for their breach, relying primarily on the goodwill of the EPFI to implement them properly. However, the EPs ae now subject to a number of criteria which provide for a certain degree of EPFI accountability. These are discussed further below.

\section{B. OECD Guidelines for Multinational Enterprises}

\section{What They Are}

The Guidelines were first drafted in 1976 and were most recently revised in June 2000. They are recommendations addressed to MNEs that aim to ensure that the MNE operations are in harmony with government policies.

The Guidelines provide guidance for MNEs in all major areas of business ethics, including employment and industrial relations, human rights, environmental concerns, information disclosure, corruption, consumer interests, science and technology, competition, and taxation. They are the only multilaterally endorsed and comprehensive code that governments have committed to promoting with respect to MNEs. ${ }^{18}$

The Guidelines express the shared values of the countries that house the most MNEs and are the sources of most of the world's direct investment flows. They have now been signed by the thirty OECD member countries and the following ten non-member countries: Argentina, Brazil, Chile, Egypt, Estonia, Israel, Latvia, Lithuania, Romania, and Slovenia. ${ }^{19}$

\section{How They Work}

The governments adhering to the Guidelines agree to promote their implementation by enterprises operating in the governments' territories. The OECD Decision and its Procedural Guidance provide the institutional structure for promoting the implementation of the Guidelines. There are four main elements to the implementation of the Guidelines: the National Contact Points (NCPs); the OECD Investment Committee; the Advisory Committees of Business and Labor Federations; and nongovernmental organizations represented by OECD Watch. The NCPs offer a forum for discussion and to assist the business community, employee organizations, and

18. OECD, The OECD Declaration on International Investment and Multinational Enterprises: Promoting Responsible Government and Responsible Business (2000), www.oecd.org/document/49/ 0,3343,en_2649_34487_2068145_1_1_1_1,00.html.

19. OECD, Member Countries, http://www.oecd.org/countrieslist/0,3351,en_33873108_33844 430_1_1_1_1_1,00.html (last visited Oct. 6, 2008). 
other parties concerned with implementation of the Guidelines. The NCPs meet annually to share their experiences and to report to the Investment Committee. ${ }^{20}$

When the Guidelines were revised in 2000, a new procedure was added that allowed complaints to be brought against MNEs that are not following the Guidelines. This is discussed further in Subpart C.

\section{Voluntary Initiatives Compared}

Despite the differences between the EPs and the Guidelines in their legal nature and implementation, there are a number of similarities that are interesting to highlight. ${ }^{21}$

\section{Scope of Application}

Both the EPs and the Guidelines possess international scope and application. However, while the EPs are applicable only to financial institutions that engage in project finance, ${ }^{22}$ the Guidelines have substantially broader application. The Guidelines are not limited to one particular sector (project finance) or type of MNE (financial institutions). This is perhaps the reason that the Guidelines are considerably less prescriptive than the EPs as to the precise manner in which their requirements must be implemented. It would be very difficult to create a detailed framework like the EPs that would be applicable to every area of an MNE's activities.

\section{Voluntary Nature}

Both the EPs and the Guidelines are voluntary initiatives. The Guidelines seek to strengthen the basis of mutual confidence between the MNEs and the societies in which they operate. The Guidelines also aim to help improve the climate for foreign investment and enhance the contribution to sustainable develop-

20. OECD, Implementation of the OECD Guidelines for Multinational Enterprises, http://www .oecd.org/document/43/0,3343,en_2649_34889_2074731_1_1_1_1,00.html (last visited Oct. 6, 2008).

21. These are explored further in OECD, The OECD Guidelines for Multinational Enterprises and the Equator Principles-Similarities, Differences and Synergies, OECD Doc. DAF/INV/ NCP(2007)3, available at http://www.cedha.org.ar/en/initiatives/corporate_social_liability/eps_ and_gls.pdf.

22. Project finance is based upon a structure where project debt and equity are used to calculate financing. It is commonly associated with, for example, the development of mining, pipeline, and other infrastructure projects. A syndicate of banks usually provides loans to the project, which are secured by the project itself and repaid from the project's cash flows. 
ment made by MNEs. Although not expressly stated in the EPs, the same considerations apply to the EPFIs with respect to their project finance activities.

\section{Public/Private Nature}

The EPs and the Guidelines are similar instruments in their legal nature. Neither the EPs nor the Guidelines contain a detailed set of enforceable legal norms, but rather a general, voluntary framework of principles and standards. However, while the EPs are purely private, endorsed only by EPFIs, the Guidelines are signed by national governments and contain recommendations to MNEs operating in their territories.

\section{Internal Procedures and Accountability}

Both the EPs and the Guidelines provide similar advantages for MNEs and EPFIs in terms of organization and management, internal and external accountability, and harmonization of practices with competitors. They provide a framework within which entities can consider the ways in which they interact with their stakeholders. This serves as a checklist against which they can review and implement their practices. The fact that the EPs and Guidelines provide a common framework applicable to other EPFIs or MNEs means that they can compare their activities with those of their peers. It also makes organizations more susceptible to comparison by stakeholders, providing stakeholders with a uniform benchmark against which to judge the organization, thereby instilling accountability.

\section{Social and Environmental Standards}

In comparison with the EPs, the environment chapter of the Guidelines is narrower in that it provides only for an environmental impact assessment rather than a social and environmental impact assessment. However, the Guidelines do highlight the need to address the foreseeable environmental, health and safety impacts associated with the processes and goods and services in the business' decision making. The Guidelines suggest a framework for the consideration of an organization's general environmental impacts. ${ }^{23}$

The Guidelines are particularly comprehensive with respect to environmental management systems (EMS). They provide that EMS should include the collection and evaluation of information regarding the environmental, health and safety impacts of enterprises; the establishment of quantifiable objectives and targets for improved environmental performance; and the regular monitoring of

23. OECD Guidelines, supra note 7, at 22-24. 
progress in reaching those objectives. This is a potentially high benchmark, but EMS does provide substantial room for varying levels of implementation.

Unlike the EPs, which are based on the IFC's Safeguard Principles, the EMS required by the Guidelines are not based on uniform standards and are not benchmarked. There are several different models of EMS: externally certified EMS (like ISO 14001); European Union's Eco-Management and Audit Scheme (EMAS); and performance-based EMS and sector-specific EMS (for example, EMS for the chemical and the financial sectors).

\section{Sanction for Breach}

The EPs provide little external interference if they are breached by EPFIs. In contrast, pursuant to the Guidelines, the NCPs have a duty to manage complaints relating to MNEs registered within or operating from their countries. NCPs accomplish this by facilitating dialogue and mediation between the two parties. If they determine that the company has breached the Guidelines, the NCPs issue a statement making recommendations to the company on how it could bring its future practices in line with the Guidelines. Further, the Guidelines provide interested parties the right to submit complaints concerning the activities of companies. ${ }^{24}$

\section{Evaluating Voluntary Initiatives Against the Porter-Kramer Tenets}

\section{A. The Tenets}

Porter and Kramer suggest how businesses can successfully integrate business and social responsibility. The key tenets of their recommended strategy require companies:

(a) to identify the points of intersection between a company and a society;

(b) to choose which social issues to address;

(c) to create a corporate social agenda;

(d) to integrate inside-out and outside-in practices; and

(e) to construct a social dimension to the value proposition. ${ }^{25}$

24. "According to the OECD, by June 2005, over 100 complaints had been filed by NGOs and trade unions since the Guidelines were revised." OECD WATCH, FIVE YEARS ON: A REviEW OF THE OECD Guidelines and National Contact Points 5 (2005).

25. Porter \& Kramer, supra note 8, at 84-90. 
Their central message ${ }^{26}$ is that if "corporations were to analyze their prospects for social responsibility using the same frameworks that guide their core business choices, they would discover that CSR can be much more than a cost, a constraint, or a charitable deed-it can be a source of opportunity, innovation, and competitive advantage."27

Voluntary initiatives could play an important role in allowing MNEs and EPFIs to implement Porter and Kramer's vision, provided that they are structured in an appropriate manner. Nonetheless, the implementation of the model set out by Porter and Kramer is not without its challenges, and implementing such a cultural shift will be too difficult for many organizations.

\section{B. Identification of the Points of Intersection Between a Company and a Society}

This section of the article evaluates the EPs and Guidelines against the criteria discussed above to determine the extent to which they contribute to MNEs' ability to fulfill Porter and Kramer's ambition for CSR initiatives (that is, to be a source of opportunity, innovation, and competitive advantage).

Porter and Kramer suggest that to optimize the implementation of CSR initiatives, companies must begin by identifying the points of intersection between the company and society. They differentiate between "inside-out" and "outsidein" linkages. ${ }^{28}$ The former are the impositions that a company makes through its operations in the normal course of business; the latter are external social conditions that influence companies.

EPFIs; which are typically large financial institutions, have significant insideout linkages. These include their direct energy and water use, the services that they provide to the public, and their overall impact on the global economy. Financial institutions that take the time to implement in accordance with the EPs, particularly the founding members of the EP, are likely to be among the banks that best identify their inside-out linkages. Many EPFIs issue extremely comprehensive CSR reports that illustrate many or all of these inside-out impacts. EPFIs

26. Herman B. Leonard \& W. Kasturi Rangan, Corporate Social Responsibility Strategy and Boards of Directors, BOARDROOM BRIEFING, Dec. 2006, at 12, available at http://www.directorsan dboards.com/DBEBRIEFING/December2006/Winter06BB.pdf.

27. Porter \& Kramer, supra note 8 , at 80.

28. Id. at 84 . 
benchmark and report on their social and environmental impacts on a regular basis. ${ }^{29}$ The same is true of many MNEs. ${ }^{30}$

However, as Porter and Kramer state, in relation to inside-out linkages, "[w]hile companies are increasingly aware of the social impact of their activities (such as hiring practices, emissions, and waste disposal), these impacts can be more subtle and variable than many managers realize. For one, they depend on location."31 This is particularly true in the case of project finance, where the extent of the bank's responsibilities for funding projects that have massive social and environmental impacts is difficult to delineate. When does a bank's responsibility for the environmental and social issues cease in a situation where, without the finance provided by that bank, a project would not proceed?

While the EPs apply only to a relatively small part of most EPFIs' activities (they apply only to project finance lending and advisory activities and not, for example, to its trading or retail banking activities), they nonetheless require a very detailed analysis by EPFIs of the intersection between the bank's activities and the society in which it operates. This is illustrated not only by the detailed social and environmental impact assessments that EPFIs require borrowers to carry out but also by the implementation of action plans, consultation, and grievance procedures. ${ }^{32}$ The same is true of MNEs that are conducting their affairs in accordance with the Guidelines. ${ }^{33}$

"Outside-in" linkages consist of the ability to recruit high quality personnel; the rules relating to competition, bribery, and corruption; the size and sophistication of local demand; and the local availability of supporting industries. Again, these are often delineated in EPFIs' and MNEs' CSR reports, which usually identify a broad range of stakeholders and regulations by which the EPFI or MNE is bound. In the areas of project finance, there are a number of specific linkages that have caused concern in the past. For example, there are reputational concerns when dealing with the impact that projects have on affected communities, as well as the social and environmental consequences of funding certain projects.

Of course, EPFIs could be criticized for not extending the scope of the EPs

29. See Equator Principles, Become an Adopting Institution, http://www.equator-principles .com/join.shtml (last visited Dec. 14, 2008) (providing CSR reports for all EPFIs).

30. KPMG recently indicated that $80 \%$ of the world's largest companies now report on CSR. KMPG InT'L, KMPG INTERNATIONAL SURVEY OF CORPORATE RESPONSIBILITY REPORTING 2008, at 13 (2008), available at http://www.kpmg.com/SiteCollectionDocuments/International-corporate -responsibility-survey-2008.pdf.

31. Porter \& Kramer, supra note 8 , at 84.

32. See supra Table 1.

33. See supra Part II.B. 
beyond project finance and hence not requiring detailed analyses of EPFIs' points of intersection. However, project finance is one of the few areas of an EPFI's activities where the EPFI is likely to have direct contractual control as a lender over the borrower's activities. In the case of day-to-day corporate lending, the bank may have very little involvement in the borrower's activities. In project finance, lenders have the opportunity to scrutinize the borrower's intended activities to a much greater degree. In recognition of the myriad significant environmental and social issues at stake, EPFIs have identified project finance as an important area where their activities most closely intersect with society. It appears, therefore, that the EPs have been successful, to a degree, in supporting EPFIs in the identification of linkages between EPFIs and society.

The Guidelines address the foreseeable environmental, health and safety impacts associated with the MNE's processes and goods and services. Unlike the EPs, they do not provide for an action plan or management system. They are less specific in their application than the EPs (relating, as they do, to the whole of the organization's operations). While the EPs impose no requirement on the EPFIs to consider their own behavior (applying only to assessment of the proposed project by borrowers), the Guidelines encourage MNEs to consider their own environmental impacts by suggesting a framework for assessing the general environmental impacts of an organization. ${ }^{34}$

The fact that the EPs set out a detailed list of criteria to be considered by EPFIs when engaging in project finance activities ${ }^{35}$ means that EPFIs are forced to look beyond their own activities and consider the broader social and environmental impacts of the projects they are funding. For example, the EPs require banks, through their borrowers, to take into consideration project-affected communities. However, in contrast to the Guidelines, the EPs are largely silent on the bank's own internal organization, save to the extent that EPFIs will implicitly be required to maintain the implementation of the EPs and provide mechanisms, such as staff training programs, for their implementation.

\section{Choosing Which Social Issues to Address}

The EPs are only one element in a broad spectrum of many EPFIs' CSR agendas. However, in the case of an EPFI with more limited resources and in ju-

34. OECD Guidelines, supra note 7, at 22-24.

35. These activities are backed up by the IFC Safeguard Standards and further sector-specific guidance. 
risdictions where CSR is less developed, the EPs are still likely to play a significant part in their CSR strategies. The Guidelines underlie a broader spectrum of MNE's activities.

In choosing which social issues to address, Porter and Kramer suggest that companies should differentiate between the following:

- "generic social issues" (those which may be important to society but are neither significantly affected by the company's operations nor influence the company's long-term competitiveness);

- "value chain social impacts" (those that are significantly affected by the company's activities in the ordinary course of business); and

- "social dimensions of competitive context" (those facts that significantly affect the underlying drivers of competitiveness where the company operates).$^{36}$

Further, "[t]he essential test that should guide CSR is not whether a cause is worthy but whether it presents an opportunity to create shared value - that is, a meaningful benefit for society that is also a value to the business." ${ }^{37}$

The EPs act at all three of the levels identified above. The adoption of the EPs represents a response to a generic social issue, which requires that financial institutions play an important role in shaping the world's economy. Their policies can also have significant environmental and social impacts. Further, dealing effectively with the social and environmental aspects of a project in order to circumvent regulatory issues, court cases, and delays in project implementation constitute significant value chain social impacts.

Implementation of the EPs represents a means of addressing one of the areas in which EPFIs have the greatest, albeit indirect, social and environmental impact. There is a link between the implementation of the EPs and value for the EPFIs. For instance, the extent to which EPFIs are seen as attractive lenders or partners in a loan syndicate because of their implementation of the EPs, or the extent to which only non-EPFIs are able to finance projects that the EPs would not allow an EPFI to finance, indicates that the EPs have the ability to raise issues that constitute social dimensions of a competitive context.

Whereas the EPs currently address only one part of EPFIs' CSR agendas, the Guidelines are sufficiently generic for them to be able to set out a framework for the whole range of a company's behavior. Superficially, this is advantageous as it means that MNEs are provided with a broader framework for the implementation of their

36. Porter \& Kramer, supra note 8, at 85.

37. Id. at 84 . 
CSR agendas. However, Porter and Kramer highlight the importance of an MNE's choice of which social issues to address, and the imperative of identifying "social dimensions of competitive context." These are the facts that significantly affect the underlying drivers of competitiveness in places where the company operates. While the sectoral approach of the EPs illustrates that EPFIs have concentrated on an area of their business most exposed to risks associated with poor environmental and social performance, the Guidelines are insufficiently specific to guide MNEs in their identification of particular social issues. Nevertheless, the suggestion that MNEs implement EMS is likely to draw their attention to those areas of greatest environmental impact. The failure of the Guidelines to provide for social assessment is a significant omission in this respect.

\section{Creating a Corporate Social Agenda}

Porter and Kramer differentiate between "responsible" and "strategic" CSR, stating that it is through strategic CSR that the company will make the most significant social impact and will reap the greatest business benefits. The fact that an EPFI has adopted the EPs should be seen as an important part of an EPFI's social agenda. However, the EPs were never intended to be an implementing framework beyond project finance. Therefore, it is not surprising that the EPs have little to offer with respect to creating an overall corporate social agenda.

Strategic CSR involves "both inside-out and outside-in dimensions working in tandem." ${ }^{38}$ Credit Agricole (now Calyon), which offers specialist financial products related to the environment, such as financing improvements for energy-efficient home products, is one example of this type of strategic CSR. It could be argued that the EPs constitute a new kind of strategic financial product in the project finance market, in which case this would be an example of the EPs making a small step into the crucial zone of "strategic CSR." It also has been argued that the EPs should be extended to cover forms of financing other than project finance. ${ }^{39}$ For example, the EPFIs could apply EP-like criteria on a sectoral basis, such as all lending in the forestry sector, regardless of whether or not the lending is project finance. ${ }^{40}$ Although the idea has been rejected by some leading bankers, if the EPs were extended more broadly, financial institutions may further integrate social and environmental concerns and thus participate in a more inclusive type of "strategic CSR." The imple-

38. Id. at 88 .

39. Freshfields BruCKhaus DeRINGer, supra note 14 , at 71 .

40. Id. 
mentation of a sector-specific approach that sets out environmental and social criteria for different kinds of financial activities is a viable alternative.

The generality of the Guidelines, in contrast with the EPs, successfully provides for the creation of a broader corporate social agenda. This is because the Guidelines require decision-making processes to address the business' foreseeable environmental, health and safety impacts. While it is possible to adhere to this criterion without creating a corporate social agenda, the thrust of the Guidelines requires these issues to be considered holistically, both up and down the supply chain. This holistic approach is helpful in creating a corporate social agenda.

The Guidelines, however, provide no impetus for the creation of a "strategic" CSR agenda. They do not require MNEs to adopt CSR strategies that take into account the positive rewards that can be reaped where inside-out and outside-in dimensions work in tandem. The EPs promote a relatively more strategic approach to CSR.

\section{E. Integrating Inside-out and Outside-in Practices}

Linked to Porter and Kramer's idea that CSR should be strategic is the view that "inside-out" and "outside-in" practices should be integrated. An example of such integration is Marriott Hotels working with community groups to provide training to chronically unemployed job candidates, many of whom subsequently take jobs with Marriott. ${ }^{41}$ The EPs attempt to improve EPFIs' reputations, and possibly their bottom lines, through the application of high standards to project finance transactions. However, in order to fully integrate inside-out and outsidein linkages, the EPs have to go further. It is difficult to see how this could be done in the context of project finance. One possibility is that, where appropriate, EPFIs could integrate the development of EP projects with microfinance initiatives into communities affected by the projects. However, it is likely that the creation of such virtuous circles would be seen as artificial and that the EPs would not be considered the appropriate forum for implementing such schemes.

The apparent weakness in the Guidelines is the lack of specificity in the identifying inside-out and outside-in practices beyond the most generic factors in the decision-making process. The Guidelines fail the Porter and Kramer criterion of integrating such practices. Having been provided with a general framework for the consideration of CSR issues, MNEs are likely to increasingly engage in such integra-

41. Porter \& Kramer, supra note 8 , at 89. 
tion. Nonetheless, the Guidelines, beyond merely encouraging MNEs to match best practices, do not set out a specific requirement or framework for this to take place.

\section{F. Creating a Social Dimension to the Value Proposition}

Finally, Porter and Kramer argue that "[ $[\mathrm{t}] \mathrm{he}$ most strategic CSR occurs when a company adds a social dimension to its value proposition, making social impact integral to the overall strategy." ${ }^{22}$ General Electric's Ecomagination provides an illustrative example. ${ }^{43}$ It is important to note that for some brands, such as Whole Foods Market, social issues are fundamental to their value proposition. This is unlikely to be the case for a financial institution, particularly with regard to the implementation of environmental initiatives. Nonetheless, some international banks appear to create a social dimension to their value proposition.

For example, Deutsche Bank's Microcredit Development Fund (DB MDF), launched in 1998, is a financial tool fuelling microfinance programs around the world. "Since its inception, the DB MDF has invested over a total of $\$ 3.4$ million in loans to some 35 microfinance institutions in 21 countries, enabling more than $\$ 42$ million to be leveraged in private financing lending capacity to the very poor." ${ }^{.44}$ In this way, there are opportunities for financial institutions to integrate social concerns with value, regardless of whether the EPs are the most appropriate vehicles for doing so.

In another recent, exciting, and potentially international development involving green buildings, a partnership of leaders in the capital markets is attempting to stimulate the global economy, stop irreversible and dangerous climate change, and promote global sustainability by introducing "sustainable mortgage backed securities" (MBS) into the international mortgaged backed securities market. The partnership consists of investment banks, investors, national governments, and non-governmental organizations. It has completed the due diligence needed to launch sustainable MBSs within existing bank operations in the $\$ 4$ trillion global MBS market. Sustainable MBSs are essentially bonds backed by a pool of green building mortgages. Investment banks have submitted sustainable MBSs to rating agencies. If sustainable MBSs penetrate the global market for mortgage securiti-

42. Id. at 89-90.

43. GE Ecomagination: Our Commitment, http://www.ge.ecomagination.com/site/ (last visited Oct. 6, 2008).

44. Deutsche Bank, Corporate Social Responsibility: Microfinance, http://www.communityuk .db.com/microfinance.php (last visited Oct. 6, 2008). 
zations, the benefits may stimulate the global economy, improve energy security, and help prevent climate change by encouraging green credentials for properties. The success of this initiative is likely to hinge on a recovery from the ongoing global "credit crunch" that has blighted the asset-backed securities market.

As with the EPs, the Guidelines are relatively unsuccessful in encouraging MNEs to create a social dimension to the value proposition beyond encouraging them to take CSR-related issues seriously. This is perhaps the central failure of the generic guidance offered by non-specific voluntary initiatives. Initiatives that require companies to consider in greater detail the interrelationships between themselves and society, and subject such relationships to review, are more likely to generate the kinds of competitive advantages that Porter and Kramer argue ought to result from high-quality CSR.

\section{How the Lack of Formal Legal Sanction is Addressed}

The above Part illustrates that, judged against Porter and Kramer's criteria for the implementation of successful (competitive) CSR that moves beyond the purely philanthropic, the EPs and the Guidelines have had some success, but there remains substantial room for improvement. One factor that Porter and Kramer do not address is the criticism that the voluntary nature of such initiatives makes them inherently flawed. This Part aims to show that there are processes and procedures that can be put into place to address the lack of formal redress or sanction. ${ }^{45}$

\section{A. Reasons for Adoption}

Many different reasons have been advanced by EPFIs for adopting the EPs and MNEs for acting in accordance with the Guidelines. These include the protection of reputation, defense against civil society activism, and matching sector best practices. ${ }^{46}$ Such organizations are likely to be cautious about reneging on the commitments to which they have agreed and thereby sacrificing the many benefits that lead them to adopt the EPs. When organizations sign on to voluntary initiatives, they are generally unlikely to actively seek to expose themselves to criticism by acting in a way that is wholly inconsistent with such initiatives.

45. Formal sanctions could take the form of civil penalties such as the imposition of fines, the binding decision of regulators to bar particular behavior, or putting a particular procedure into place. They need not require the imposition of criminal sanctions.

46. Freshfields Bruckhaus Deringer, supra note 14, at 71. 


\section{B. High-Level Commitment}

With respect to the EPs, many leading figures in the banking community have demonstrated a commitment to social and environmental responsibility. ${ }^{47}$ Project finance is particularly sensitive to such considerations. It is clear that the pressure to live up to this commitment is driven from the leadership, and that many bankers will be concerned that financing a project without properly complying with the EPs risks the wrath of senior management. The same is likely to be true with respect to MNEs that implement the principles set out in the Guidelines. As the Guidelines are adopted by governments, this "high-level commitment" should also be imposed on MNEs by governments keen to ensure that MNEs for which they are "responsible" act in accordance with Guidelines.

\section{Reputation}

EPFIs have sought reputational protection by adopting the EPs. ${ }^{48}$ The EPs allow EPFIs to hold themselves out as responsible lenders by complying with widely adopted "best practice" standards. This reputational advantage is supported by the fact that the EPs are underpinned by the IFC's Safeguard Policies. Banks and financial institutions continue to suffer damage to their reputations from lending practices perceived as irresponsible. Adoption of the EPs helps to guard against this damage.

These factors also apply to MNEs with respect to the Guidelines. The tendency of civil society to monitor and report on MNEs' performance, especially against the obligations set out by the EPs and the Guidelines, can only mean that EPFIs and MNEs are under increasing reputational pressure to comply with them. ${ }^{49}$ EPFIs and MNEs in general are also likely to be concerned with how they are perceived by industry regulators and fund and asset managers who monitor social and environmental impacts.

\section{Compliance Adviser/Ombudsman}

There are currently no formal provisions in the EPs to sanction entities that engage in "greenwash" by adopting the EPs but failing to properly implement them. It has been argued that it would be useful to provide a compliance adviser

47. Id. at 56.

48. Id.

49. Id. at 7 . 
and ombudsman to advise third parties on issues relating to a project and to monitor and regulate the implementation of EPs. On the other hand, the Guidelines set out a clear process for parties to make complaints.

As critics of the Guidelines are quick to point out, such a mechanism is not in itself foolproof. For example, in the opinion of OECD Watch, five years after the latest reform of the Guidelines,

OECD Watch has determined there is no evidence that the Guidelines have helped to reduce the number of conflicts between local communities, civil society groups and foreign investors. As a global mechanism to improve the operations of multinational enterprises and contribute to a reduction in conflicts on social, environmental and human rights issues, experience with the Guidelines over the past five years demonstrates they are simply inadequate and deficient. Moreover, without the threat of effective sanctions, there is little incentive for companies to ensure that their operations are in compliance with the Guidelines. ${ }^{50}$

\section{E. Protection of Market Share and Differentiation}

As the number of EPFIs increases, it becomes more difficult for EPFIs to differentiate themselves by adopting the EPs. Nevertheless, it remains likely that the increased due diligence required by the EPs means that projects will be shielded from at least some adverse criticism by stakeholders. ${ }^{51}$ EPFIs are therefore likely to want to properly implement the EPs in order to more successfully manage projects by reducing costly delays caused by poor social planning and ill-considered environmental consequences. Although this consideration applies less to MNEs with respect to the Guidelines, they are still likely to comply due to moral considerations. Reputable global players are likely to wish to avoid being seen as one of a diminishing group of entities that do not apply widely adopted social and environmental standards.

50. OECD WATCH, supra note 24 , at 45.

51. Id. at 59. 


\section{F. Syndication}

Finally, with respect to the EPs, project sponsors are likely to encourage banks to adopt the EPs if it becomes the case that compliance leads to more successful project syndication. Syndication difficulties can increase costs, have a negative effect on reputation, and make it harder to attract finance for future projects. The length of time and cost of syndication might also increase if arrangers invoke provisions in their mandate letters that allow them to withdraw from arranging financing if there is insufficient take-up from the market as a result of the project not being compliant.

\section{G. Moves Toward Formal Sanction}

The factors outlined above can be seen as purely informal mechanisms of sanction for breach of the requirements of the EPs and the Guidelines. The Guidelines contain provisions that have the hallmarks of more formal sanctions, and EP2 has introduced three additional methods of sanction, which it was hoped would encourage compliance with the EPs and increase accountability. These include obligations to put in place independent review, grievance procedures, and annual reporting obligations.

\section{Mediation, Conciliation, and Grievance Procedures}

Under the Guidelines, NCPs are required to contribute to the resolution of issues that arise relating to implementation of the Guidelines. ${ }^{52}$ They offer a forum for discussion and assist the business community, employee organizations, and other concerned parties in dealing with the issues in an efficient and timely manner and in accordance with applicable law. ${ }^{53}$ The role of NCPs includes offering and facilitating access to consensual and non-adversarial means, such as conciliation or mediation. ${ }^{54}$

Parallels can be drawn between this and the consultation and grievance mechanisms set out in the EPs. EP2 requires a grievance procedure to be put in place during a project's lifetime for the benefit of project-affected communities. ${ }^{55}$ It nevertheless falls far short of fully addressing the lack of accountability in implementing the EPs. In light of several recent, well-publicized projects, there has been a call for sponsors

52. OECD Guidelines, supra note 7 , at $36-37$.

53. Id.

54. Id. at 36.

55. Equator Principles, supra note 6, princ. 6. 
and for EPFIs to become more transparent and accountable to both the communities affected directly by such projects and to civil society generally. ${ }^{56}$

\section{Loan Document Covenants}

The lack of formal legal sanction of the EPs has been partly addressed in EP2 by the introduction of loan covenants. ${ }^{57}$ They are intended to trigger a default under the financing arrangements when there is non-compliance with the EPs, potentially allowing the EPFIs to accelerate repayments of any loans. However, the introduction of these covenants actually represented a codification of existing practice. For example, most loan documents already had a covenant requiring the borrower to comply with local laws.

\section{Independent Review}

For all Category A projects and, where appropriate, Category B projects, EPFIs can require independent review by a social or environmental expert not directly associated with the borrower. The scope of the review that the independent expert may be requested to carry out includes the environmental and social impact assessment, action plan, and consultation process documentation. ${ }^{58}$ The purpose of the review is to assist an EPFI in its due diligence of the development and operation of the project and its compliance with the EPs.

\section{Annual Reporting Obligations}

EP2 requires EPFIs to provide public reports at least annually. ${ }^{59}$ The report must cover implementation of the EPs processes and the experience of the EPFI, subject to the requirements of client confidentiality. At a minimum, the report should address the number of transactions screened by the EPFI and the categorization of each transaction, as well as information on the implementation of the EPs. In addition, the EPFI report may include a breakdown of transactions and categorizations by sector or region.

\section{Toward Accountability?}

When taken together, the introduction of grievance procedures, independent

56. BankTrack, Principles, Profits or Just PR? Triple P Investments Under the PrinciPLES (2004), http://www.foe.org/res/pubs/pdf/princprofspr.pdf.

57. See supra Table 2 and accompanying text.

58. Equator Principles, supra note 6, princ. 7.

59. Id. princ. 10. 
expert appraisal, and community consultation have created a more powerful arsenal of tools with which EPFIs and civil society can more effectively monitor compliance with the EPs. This reinforces the significance of the less coercive, but equally important, sanctions of loss of reputation and falling below internal and market expectations. It remains to be seen whether future developments in the EPs will lead to the introduction of more formal methods of holding EPFIs to account.

With respect to the EPs, the fact that there are no formal legal sanctions for their breach does not mean that they are fundamentally flawed from a CSR perspective. In fact, their lack of legal sanction is likely to have contributed substantially to the enthusiastic adoption of the EPs. However, it fails to establish the value of the EPs above and beyond the reasons for their adoption outlined in the previous sections of this article. Further, the Guidelines have, since 2000, benefited from a more detailed procedure for enforceability than the EPs. On the other hand, these procedures are not regarded by all stakeholders as adequate or even effective.

\section{IMPROVING EFFECTIVENESS OF VOLUNTARY INITIATIVES}

In light of the somewhat disappointing, if not inevitable, conclusion that the EPs and the Guidelines could go further than they currently do in implementing a CSR agenda that reaps maximum competitive advantage for EPFIs and MNEs, what is the future for such voluntary initiatives?

\section{A. Tightening Up Existing Voluntary Initiatives}

One approach would be to insist on the increased tightening and proliferation of existing voluntary initiatives. For example, the EPs could be extended to a broader range of financing and could apply its more onerous criteria to all, not merely Category A, projects. The Guidelines could specify the kind of EMS to be put in place, and the requirement for EMS could be extended to include social impacts. On its own, however, a mere tightening of voluntary initiatives is not likely to lead to the cultural shift that Porter and Kramer believe is necessary.

\section{B. Increase in Number or Consolidation of Initiatives}

An alternative approach would be to encourage adoption and implementation of further voluntary CSR initiatives. While this may at first appear attractive, 
if further CSR initiatives are introduced (as seems inevitable), it would be wise for them to encourage businesses to confront the strategic issues raised by Porter and Kramer when designing them. However, there is a significant risk that MNEs, the public and civil society will become overwhelmed by a seemingly endless array of voluntary initiatives. This could lead to CSR being perceived as a smokescreen rather than a force for good.

\section{Ombudsman and Grievance Mechanisms}

The lack of accountability with respect to voluntary initiatives is met with significant criticism. It creates distrust about whether such initiatives are being actively enforced and properly implemented and leads to accusations of "greenwash." This problem can be tackled through a number of changes. Each voluntary initiative should ideally provide for an ombudsman to whom concerns can be referred by any party for review. The ombudsman should also be responsible for handling implementation questions from entities implementing the initiative. However, this is not a panacea. NCPs effectively act as an ombudsman, but this has not eliminated all critiques of the Guidelines.

\section{Reporting}

Reporting on the incidence of compliance (and non-compliance) with voluntary initiatives is likely to improve the implementation of initiatives by MNEs and also the public trust in the quality of implementation. Disclosure should be made available on MNEs' websites and should conform to pre-determined criteria set by the ombudsman. An ombudsman should report on implementation at least annually and set out recommendations for change. Organizations that fail to meet disclosure criteria should be "de-listed" and, as a consequence, subject to public sanction.

\section{E. Cross-over of Voluntary and Mandatory Regimes}

In many instances, formal regulators, such as states and local authorities, are already turning to standards that have been voluntarily adopted and implemented by MNEs. One example of this is the requirement that buildings conform to volun- 
tary "green buildings" standards, such as BREEAM ${ }^{60}$ and LEED. ${ }^{61}$ Another example is the U.K.'s Renewable Transport Fuels Obligation (RTFO), ${ }^{62}$ which relies on a number of voluntarily adopted standards relating to the social and environmental performance of biofuel feedstocks. ${ }^{63}$ The cross-over of such voluntary and mandatory regimes is likely to enhance the penetration of CSR and also to improve the quality and consistency of their implementation. For example, under the RTFO, in the future, biofuels that do not meet qualifying voluntary standards may not receive public subsidy by generating valuable renewable certificates. ${ }^{64}$

\section{F. Certification}

Many voluntary initiatives rely on a process of certification. A certificate is produced to show that an entity has complied with the initiative's requirements. Certification requires administration and thus adds cost and complexity to voluntary regimes. However, it does provide a useful means of verifying compliance with recognized standards. Certification can be integrated into the functions of an ombudsman, though this may lead to accusations of conflicts of interest. This could also pave the way for trading of such certificates.

\section{G. Securing International Mandates}

The vast array of voluntary initiatives already available to MNEs is further complicated by the adoption of different voluntary standards in different countries of regions concerning similar issues. Conflicts between voluntary standards, such as U.K. and U.S. versions of green building codes, cause uncertainties and implementation difficulties. This also highlights the importance of securing international mandates for voluntary initiatives. Although it may not be possible to generate a "one size fits all" solution for all jurisdictions, where possible this should be done.

60. Building Research Environmental Assessment Method, http://www.breeam.org/ (last visited Oct. 6, 2008).

61. U.S. Green Building Council, Leadership in Energy and Environmental Design (LEED) Rating Systems, http://www.usgbc.org/DisplayPage.aspx?CMSPageID $=222$ (last visited Oct. 6, 2008).

62. This is effectively a biofuels subsidy.

63. Roundtable on Sustainable Oil, http://www.rspo.org/Key_documents.aspx (last visited Oct. 6, 2008).

64. See Consultation on the Draft Renewable Transport Fuel Obligations (Amendment) Order 2009, http://www.dft.gov.uk/consultations/open/rftoorder/ (last visited Nov. 25, 2008). 


\section{H. Changes in Perception}

The steps outlined above are likely to improve both the perception and the quality of voluntary initiatives. They do not, on their own, address Porter and Kramer's vision of the implementation of a more strategic kind of CSR. If existing and future voluntary initiatives are to lead to the kind of CSR cultural shift that Porter and Kramer believe is required, a paradigm shift must first occur in the perception of both those who are designing and implementing such initiatives and public expectations regarding such initiatives' goals.

Though MNEs are very aware that CSR can generate competitive advantages, they appear to be ashamed to admit openly that CSR will be most effective when it works in harmony with sound business strategy, and therefore, fail to integrate CSR with their everyday business activities. MNEs' nervousness is perhaps not surprising given the array of non-governmental organizations monitoring their CSR performance. However, openness in relation to this issue by MNEs is likely to lead to better CSR, which will have more lasting positive effects. Such a shift in perception must also be matched by a change in the general public's expectations of how CSR initiatives can best be implemented.

\section{Taking a More Strategic Approach}

Following Porter and Kramer's reasoning, MNEs must begin to implement the competitive advantages that CSR can unlock by integrating their CSR initiatives with the core activities of their business. This process of unlocking value will doubtless be improved if existing and future voluntary initiatives are designed in a way that forces MNEs to consider the inside-out and outside-in social linkages that exist and to construct a social agenda for the company based around such linkages.

Companies should therefore be more strategic in choosing which voluntary initiatives to adopt. They should also redesign existing initiatives in a way that will encourage participants to take a more strategic approach. This could be done, for example, by encouraging reporting and disclosure of the competitive synergies to which such initiatives are leading. Companies could be encouraged to report on the social and economic benefits that have accrued not just to the beneficiaries of CSR but also to the MNE itself. 


\section{Conclusion}

The rise of voluntary CSR initiatives has been meteoric. As the CSR market matures, it would be advisable for MNEs to assess the extent to which voluntary initiatives are being promulgated in ways that best serve the needs of the business community and society at large. Piecemeal attempts to improve performance in particular sectors, while leading to positive improvements, are unlikely to fully serve those needs, nor are very general, broad-brush initiatives that set out a loose framework for the consideration of CSR values by MNEs.

In relation to both the EPs and the Guidelines, formal enforcement mechanisms would benefit both legal instruments and the accountability of EPFIs and MNEs that have adopted the Guidelines, and would enhance the robustness of the rules provided. On the other hand, formal legal redress substantially may discourage adoption of the EPs and the Guidelines. It may therefore be desirable to first put in place a number of less formal penalties before formal sanctions are imposed.

A fundamentally different approach to CSR that accrues benefits not just to its stakeholders but to the company itself should be implemented. If properly done, this would have the effect of encouraging MNEs to engage in more extensive CSR activities to improve shareholder value and create net gains for the external beneficiaries of CSR.

Few people have suggested models for the implementation of a more competitive approach to CSR, though companies like Marriott and General Electric have begun to live by its tenets. One model for taking a more organized approach that analyzes and exploits horizontal and vertical linkages of environmental and social benefit with business' existing expertise is the one set out by Porter and Kramer. Though the deteriorating global economic outlook of the late 2000s may put wholesale reform of CSR on the backburner, perhaps this will be the CSR success of the coming decade. 